\title{
Pengaruh Model Pembelajaran Science Environment Technology Society Terhadap Hasil Belajar Ilmu Pengetahuan Alam
}

\author{
Ni Made Sri Sukmawati ${ }^{*}$, I Made Citra Wibawa², Putu Aditya Antara³ \\ 1,2Jurusan Pendidikan Guru Sekolah Dasar (PGSD), Universitas Pendidikan Ganesha, Singaraja, Indonesia. \\ 3 Jurusan Pendidikan Guru Pendidikan Anak Usia Dini (PGPAUD), Universitas Pendidikan Ganesha, Singaraja, Indonesia
}

\begin{tabular}{l} 
A R T I C L E I N F O \\
\hline Article history: \\
Received 19 May 2018 \\
Received in revised form \\
07 June 2018 \\
Accepted 10 July 2018 \\
Available online 20 August \\
2018 \\
\hline Kata Kunci: \\
Science Environment \\
Technology Society (SETS), \\
Hasil Belajar \\
Keywords: Environment \\
Science $\quad$ Technology Society,The \\
Result of Learning
\end{tabular}

A R T I C L E I N F O

Received 19 May 2018

Received in revised form

07 June 2018

Available online 20 August

Technology Society (SETS),

Belajar

\begin{abstract}
A B S T R A K
Penelitian ini bertujuan untuk mengetahui perbedaanhasil belajar IImu Pengetahuan Alam antara kelompok siswa yang dibelajarkan menggunakan model pembelajaran science environment technology society dan kelompok siswa yang dibelajarkan menggunakan model pembelajaran konvensional. Penelitian ini adalah penelitian semu (quasi eksperimen),denganrancangan nonequivalent posttest only control group design. Populasi penelitian ini adalah seluruh kelas V SD di Gugus III Kecamatan Mendoyo yang berjumlah 129 orang. Sampel penelitian ini adalah kelas V SDN 8 Penyaringan dengan jumlah 21 orang dan SDN 1 Penyaringan yang berjumlah 23 orang. Sampel ditentukan menggunakan teknik random sampling. Data hasil belajar dikumpulkan menggunakan tes pilihan ganda. Data yang diperoleh dianalisis menggunakan teknik analisis statistik deskriptif dan analisis statistik inferensial (uji-t). Hasil penelitian menunjukkan bahwa terdapat perbedaan hasil belajar IImu Pengetahuan Alam antara kelompok siswa yang dibelajarkan menggunakan model pembelajaran science environment technology society dan kelompok siswa yang dibelajarkan menggunakan model pembelajaran konvensional pada siswa kelas $\mathrm{V}$ SD di Gugus III Kecamatan Mendoyo. Hal ini ditunjukkan oleh thitung $(9,707)>t_{\text {tabel }}(2,000)$. Selanjutnya, rata-rata (mean) kelompok eksperimen $(20,98)$ lebih besar daripada rata-rata (mean) kelompok kontrol(14,67).
\end{abstract}

\section{A B S T R A C T}

The research was purpose to find out the differences on learning result of natural science between group of students who have been taught using learning model science environment technology society and groups of students who have been taught using conventional learning model. This research was study quasi-experiment, with non-equivalent postttest only control group design.Population of this research is all of class V SD in Gugus III Mendoyo Sub-district amounts to 129 person. The sample of this research were class V SDN 8 Penyaringan amounts to 21 personand SDN 1 Penyaringan amounts to 23 person. The sample was determined using random sampling technique. Learning result data was collected using multiple choice test. The data obtained were analyzed using descriptive statistical analysis technique and inferential statistical analysis (t-test). The results show that there are differences of result learning Inatural science between group of students who have been taught using learning model science environment technology society and groups of students who have been taught using conventional learning model class V SD in gugus III Mendoyo subdistrict.This is show by tcount $(9,707)>$ ttable $(2,000)$. Furthermore, the experimental group average (20.98) is greater than the control group mean (14.67). Thus, the science environment technology society learning model has a positive effect on the learning result of IPA in grade V SD students in Gugus III Mendoyo Subdistrict. 


\section{Pendahuluan}

Pendidikan sekolah dasar menjadi suatu tingkatan pendidikan yang paling dasar untuk selanjutnya menempuh tingkat yang lebih tinggi, oleh sebab itu seorang pendidik harus bisa mendidik peserta didik agar memiliki dasar pendidikan yang kuat untuk penopang pendidikan pada tingkat selanjutnya.Sebagai pendidik seorang guru harus mampu meningkatkan mutu dan kualitas dari peserta didik khususnya pada mata pelajaran Ilmu Pengetahuan Alam (IPA).

Selain kemampuan guru, pembelajaran IPA membutuhkan informasi yang lebih banyak baik itu dari buku paket, percobaan-percobaan maupun bantuan dari media teknologi untuk memahami materimateri yang diajarkan.Pada pembelajaran IPA siswa perlu mengenal lingkungan dan siswa dapat menggali informasi yang ada pada lingkungan sehingga nantinya siswa mampu memiliki pola pikir sendiri.

Sejalan dengan pendapat Samatowa (2010) "pembelajaran IPA berupaya membangkitkan minat manusia agar mau meningkatkan kecerdasan dan pemahamannya tentang alam seisinya yang penuh dengan rahasia yang tak habis-habisnya".selanjutnyaTrianto (2010) menyatakan, "pada hakikatnya IPA dibangun atasdasar produkilmiah, proses ilmiah, dansikapilmiah. IPAsebagaiprodukdiartikansebagaihasil proses berupa pengetahuan yang diajarkan, sedangkansebagai proses diartikanseluruh kegiatanilmiahuntuk menyempurnakan pengetahuan tentang gejala alamyang diajarkan dalamsekolah ataudi luarsekolah.Sedangkan sikap ilmiahtercermindari sikapjujurdalam mengumpulkan fakta-fakta saat melakukan prosespembelajaran.Pada proses pembelajaran perlu diciptakan kondisi pembelajaran IPA di SD yang dapat mendorong siswa aktif daningin tahu". Berdasarkan pendapat tersebut maka IPA merupakan ilmu pengetahuan yang mempelajari tentang hasil dari suatu proses pengamatan keadaan alam maupun gelaja-gelaja alam yang didapatkan dilingkungan sekitarnya.

Pembelajaran IPA dapat diketahui tingkat keberhasilannya, yaitu dengan berbagai cara salah satunya dengan menggunakan hasil belajar berupa nilai kognitif yang dicari menggunakan tes objektif. Sudjana (dalam Jihad, 2012) hasil belajar adalah kemampuan yang dimiliki oleh siswa setelah menjalani proses belajar. Proses pembelajaran Ilmu Pengetahuan Alam (IPA) yang selama ini diterapkan dengan tanpa adanya percobaan dan hanya menggunakan metode ceramah yang dilakukan oleh guru membuat siswanya diharuskan untuk menghafal materi pelajaran, jika tidak dilakukan maka akan mempengaruhi hasil belajar IPA.. IPA merupakan pelajaran yang kurang tepat jika dihafal, seperti pemaparan Samatowa (dalam Handayani, 2014) IPA tidaklah merupakan mata pelajaran yang bersifat hafalan belaka tetapi lebih baik diajarkan melalui percobaan yang dilakukan sendiri oleh siswa.

Metode ceramah yang diterapkan didalam proses pembelajaran selain mengakibatkan siswa hanya menghafal juga akan dapat mengurangi terjadinya interaksi antara sesama siswa dan guru dengan siswa sehingga membuat siswa menjadi pasif dan kurang berinteraksi. Berdasarkan hasil wawancara, observasi serta studi dokumen yang dilakukan di semua SD Gugus III Kecamatan Mendoyo pada tanggal 25 - 29 November 2017 ditemukan adanya permasalahan-permasalahan khususnya pada pembelajaran IPA di kelas V. Permasalahan selanjutnya yang ditemukan saat melakukan wawancara yaitu: 1) Materi pembelajaran yang diharuskan melakukan percobaan, guru jarang melakukannya jadi siswa cenderung menghafal materi tersebut. 2) Nilai hasil belajar IPA siswa masih dibawah KKM. Pada saat melakukan observasi adapun hasil yang ditemukan yaitu: 1) Pembelajaran yang sering diterapkan sekarang ini oleh guru yaitu pembelajaran yang hanya berpusat pada guru (teacher centered) dan hanya berorientasi pada buku paket dan Lembar Kerja Siswa (LKS), sehingga siswa mudah merasa bosan dan jenuh mengikuti pembelajaran. 2) kurangnya interaksi antar siswa dalam proses pembelajaran, jadinya siswa tidak memperoleh ide-ide baru atau pemikiran-pemikiran baru dari sesama siswa.

Dari permasalahan yang telah dipaparkan tersebut penyebabnya adalah karena kurangnya inovasi dan kreatifitas seorang guru didalam mengarahkan siswanya saat proses pembelajaran berlangsung, penyebab lainnya yaitu kurangnya penguasaan model-model pembelajaran oleh guru.Hasil yang didapatkan saat melakukan wawancara dan observasi tersebut dijadikan pedoman untuk memilih model pembelajaran yang digunakan sehingga nantinya model pembelajaran tersebut dapat mempengaruhi hasil belajar siswa dalam pembelajaran IPA.

Salah satu model pembelajaran yang dapat diterapkan dalam pembelajaran IPA yaitu model pembelajaran Science Environment Technology and Society (SETS).Padalangkah pembelajaran SETS nantinya siswa akan dilatih untuk memahami dan menemukan sendiri pengetahuan yang mereka pelajari. Fatchan (2014) menerangkan, modelpembelajaran Science Environment Technologi and Society (SETS) merupakan model pembelajaran yang memusatkan permasalahan dari dunia nyata yang memiliki komponen sains dan teknologi dari perspektif siswa, didalamnya terdapat konsep-konsep dan proses, selanjutnya siswa di ajak untuk menginvestigasi, menganalisis, dan merapkan konsep, dan proses itu pada situasi yang nyata. 
Binadja (dalam Rini, 2017), SETS merupakan pembelajaran yang menghubungkan sains dengan unsur-unsur lain, yaitu teknologi, lingkungan maupun masyarakat.Jadi sesuai dengan pendepat para ahli pembelajaran IPA dengan menggunakan model SETS ini akan bermanfaat bagi siswa untuk mengembangkan sikap ilmiah, selain itu juga pembelajaran IPA akan menjadi lebih menarik, menyenangkan, dan bermakna karena siswa melakukan sendiri proses pembelajarannya dan diberikan kesempatan untuk memperoleh pengetahuan tidak hanya dari buku, melainkan dengan memanfaatkan teknologi, masyarakat, dan lingkungan, maka dari itu informasi yang diperoleh siswa akan lebih banyak.

Keberhasilan dalam suatu pembelajaran yang dilakukan oleh guru di sekolah dapat dilihat dari meningkatnya hasil belajar siswa.Nawawi (dalam Susanto, 2013) menyatakan bahwa hasil belajar adalah dapat diartikan sebagai tingkat keberhasilan siswa dalam mempelajari materi pelajaran di sekolah yang dinyatakan dalam skor yang diperoleh oleh hasil belajar tes mengenai sejumlah materi pelajaran tertentu. Selain itu Rusman (2015) juga meyatakan hasil belajar adalah sejumlah pengalaman yang diperoleh siswa yang mencangkup ranah kognitif, afektif dan psikomotorik, artinya belajar tidak hanya penguasaan konsep teori mata pelajaran saja, tapi juga penguasaan kebiasaan, persepsi, kesenangan, minat bakat, penyesuaian sosial, dan keterampilan.

Dari pendapat parah ahli, dapat disimpulkan bahwa pengertian hasil belajar adalah keberhasilan yang dicapai oleh siswa dalam mempelajari materi pembelajaran yang dapat menyebabkan perubahan tingkah laku pada diri seseorang misalnya dari tidak tahu menjadi tahu, dan dari tidak bisa menjadi bisa.Perubahan-perubahan tersebut tidak hanya bisa dilihat dari aspek kognitif namun juga dapat dilihat dari aspek afektif dan psikomotor. Jadi ketiga ranah tersebut harus tercapai dalam proses pembelajaran. Hasil belajar yang diteliti dalam penelitian ini yaitu pada hasil belajar IPA yang ditekankan pada ranah kognitif (pengetahuan).

Mata pelajaran IPA merupakan ilmu pengetahuan alam yang mempelajari tentang alam beserta isinya.Menurut Harlen (dalam Samatowa, 2010) menyatakan bahwa ilmu pengetahuan alam adalah sebagian besar aktivitas mental dan praktik manusia untuk menghasilkan pengetahuan.Selanjutnya Suastra (2009:1) menyatakan bahwa, "Sains (IPA) merupakan bagian kehidupan manusia dari sejak manusia itu mengenal diri dan alam sekitarnya".Sejalan dengan pendapat tersebut Wahyana (dalam Trianto, 2010:136) menyatakan, "IPA adalah suatu kumpulan pengetahuan tersusun secara sistematik, dan dalam penggunaannya secara umum terbatas pada gejala-gejala alam".Berdasarkan urain diatas, dapat disimpulkan bahwa IPA adalah ilmu pengetahuan yang mempelajari tentang alam yang melibatkan aktivitas mental manusia untuk melakukan sebuah pengamatan yang tepat sasaran sesuai dengan prosedur sehingga mendapatkan hasil yang diinginkan.

Pembelajaran IPA sangat penting diajarkan kepada siswa disekolah dasar. Pembelajaran IPA dipelajari untuk mengembangkan pengetahuan dan pemahaman tentang konsep IPA kepada siswa itu sendiri, selain mengembangkan konsep juga perlu dikembangkan keterampilan proses yang nantinya akan berguna bagi siswa untuk melakukan sebuah pengamatan. Selain itu, dengan melakukan observasi pada pembelajaran IPA akan memberikan pengalaman langsung sehingga rasa ingin tahu siswa akan meningkat.Pembelajaran dengan meggunakan model SETS selalu memiliki keterkaitan antara sains, lingkungan, teknologi dan manusia.Hal ini membuktikan bahwa selalu adanya interaksi antar manusia, baik itu sesama manusia, maupun manusia dengan lingkungannya.Interaksi tersebut dapat mempermudah dalam mempelajari fenomena-fenomena yang terjadi pada alam maupun pada manusia itu sendiri.Oleh sebab itu pembelajaran SETS di sekolah akan membangkitkan minat berinteraksi antar sesama siswa dan lingkungannya yaitu salah satunya dengan cara melakukan diskusi.

Adapun ciri-ciri model pembelajaran SETS Menurut Sutarno (dalam Handayani, 2014) yaitu, (1) Siswa tetapdiberikan unsur-unsur pembelajaran sains, (2) Siswadibawa ke situasiuntukmemanfaatkankonsepsains ke bentukteknologi untuk kepentingan masyarakat, (3) Siswa dimintauntukberpikir tentangberbagai kemungkinanakibatyang terjadi dalamprosespentransferansains tersebutke bentukteknologi, (4) Siswa dimintauntuk menjelaskan keterhubungkaitan antara unsursains yang dibincangkandengan unsur-unsurlain dalamSETS yang mempengaruhi berbagai keterkaitanantaraunsur tersebut, (5) Siswa dibawa untukmempertimbangkan manfaat ataukerugianmenggunakan konsepsains tersebutbiladiubah kedalambentuk teknologi,dalamkonteks konstruktivisme, (6) Siswadapat diajakberbincang tentangSETS dari berbagai macamarah dandariberbagaimacam titikawal tergantungpengetahuandasaryang dimiliki oleh siswayangbersangkutan. Dari ke enam ciri-ciri tersebut dalam model pembelajaran SETS yang memiliki peran utama saat proses pembelajaran tidak lain adalah siswa itu sendiri.

Setiap model pembelajaran memiliki langkah-langkah, adapun langkah-langkah model pembelajaran Science Environment Technology Societ yaitu (1) Invitasi yaitu Guru mengemukakan informasi tentang masalah yang terkait dengan materi pembelajaran selanjutnya permasalahan yang telah diberikan oleh guru akan diamati/dipahami oleh siswa serta dapat merangsang siswa untuk bisa ikut mengatasinya. Selain itu 
permasalahan dapat juga digali dari pendapat siswa atau keinginan siswa yang ada kaitannya dengan materi pembelajaran yang akan dipelajari, (2) Eksplorasi yaitu Siswa berusaha sendiri mengumpulkan informasi berkaitan dengan permasalahan yang diberikan oleh guru melalui diskusi bersama teman, wawancara, dan melakukan observasi langsung ke lapangan dengan bimbingan dan arahan guru, (3) Solusi yaitu Berdasarkan hasil ekplorasi, siswa menganalisis permasalahan dengan melakukan diskusi kelompok bagaimana cara memecahkan masalahnya serta siswa membangun konsep baru sesuai permasalah yang berkaitan dengan materi pembelajaran sesuai dengan arahan guru, dan (4) Aplikasi yaitu Siswa menerapkan konsep-konsep yang telah dipelajarinya pada lingkungan setempat sesuai dengan arahan guru. Jadi dapat dikatakan dalam proses pembelajaran pada setiap langkah tersebut akan membuat siswa merasa tertantang untuk melakukannya, hal tersebut diharapkan akan dapat meningkatkan keberhasilan suatu proses pembelajaran IPA.

Kelebihan dari model SETS menurut Sutarno (2009) yaitu

Siswamemilikikemampuanmemandangsesuatusecaraterintegrasidengan memperhatikan keempat unsur SETS, sehingga dapat memperoleh pemahaman yang lebih mendalam tentang pengetahuan yang telah dimiliki; (2) Melatih siswa peka terhadap masalah yang sedang berkembang di lingkungan mereka; (3) Siswa memiliki kepedulian terhadap lingkungan kehidupan atau sistem kehidupan dengan mengetahui sains,perkembangannya dan bagaimana perkembangan sains dapat mempengaruhi lingkungan, teknologi dan masyarakat secara timbale balik. Selain kelebihan tersebut, Sutarno juga mengutarakan kekurangan dari model SETS di antaranya (1) siswa mengalami kesulitan dalam menghubungkaitkan antar unsurunsur dalam pembelajaran; (2) membutuhkan waktu yang lebih banyak dalam pembelajaran; (3) pendekatan SETS hanya dapat di terapkan di kelas tinggi.

Berdasarkan pendapat di atas, penerapan model pembelajaran Science Environment Technology and Society (SETS) akan memacu siswa lebih aktif dalam mengikuti proses pembelajaran, serta siswa memiliki sikap peduli terhadap lingkungan dengan begitu siswa akan mampu memecahkan masalah yang dijumpai di lingkungan masyarakat. Kelemahannya adalah dalam mengikuti proses pembelajaran membutuhkan waktu yang lebih banyak dan model ini hanya dapat diterapkan pada kelas yang tinggi, sehingga guru harus benar-benar membuat rencana pembelajaran untuk mempermudah pemahaman siswa.

Pembelajaran dengan menggunakan model Sience Environment Technology Society (SETS)berpusat pada siswa (student centered) tidak lagi berpusat pada guru (teacher centered). Siswa akan benar-benar belajar secara maksimal melalui diskusi bersama teman-temannya dan lebih banyak melakukan pengamatan, dengan melakukan sebuah pengamatan atau observasi maka ingatan siswa akan lebih bertahan lama yang nanti diharapkan dapat meningkatkan hasil belajar IPA.Oleh sebab itu dilakukanlah penelitian eksperimen yang berjudul Pengaruh Model Pembelajaran Sience Environment Technology and Society (SETS) Terhadap Hasil belajar IPA Siswa Kelas V SD di Gugus III Kecamatan Mendoyo.

\section{Metode}

Jenis penelitian yang dilakukan adalah eksperimen semu (quasi experiment).Quasi experiment merupakan sebuah penelitian yang memerlukan kelas eksperimen dankontrol, pemilihan jenis ini disebabkan karena tidak memungkinkan diadakannya pengambilan subjek (siswa) penelitian secara acak dari populasi yang ada, dikarenakan subjek secara alami telah terbentuk dalam satu kelas. Rancangan penelitian yang digunakan pada penelitian ini adalah non equivalent posttest only control group design. Populasi adalah keseluruhan kelompok yang menjadi perhatian dalam melakukan penelitian.Populasi dalam penelitian ini adalah keseluruhan kelompok siswa kelas V di SD Gugus III Kecamatan Mendoyo, Kabupaten Jembrana.Gugus iniyang terdiri dari 9 Sekolah Dasar.Jumlah seluruh populasi adalah 129 siswa.

Untuk mengetahui setara atau tidaknya kemampuan siswa kelas V masing-masing SD, terlebih dahulu dilakukan uji kesetaraan.Uji kesetaraan ini dilakukan dengan menganalisis nilai hasil UAS siswa khususnya pada mata pelajaran IPA, analisis yang digunakan dalam uji kesetaraan yaitu analisis varians satu jalur (ANAVA A).Berdasarkan hasil analisis dengan ANAVA A pada taraf signifikansi 5\% diperoleh

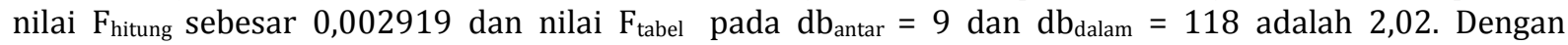
demikian, $\mathrm{F}_{\text {hitung }}$ lebih kecil dari $\mathrm{F}_{\text {tabel }}\left(\mathrm{F}_{\text {hitung }}<\mathrm{F}_{\text {tabel }}\right)$, maka $\mathrm{H}_{0}$ diterima. Jadi tidak terdapat perbedaan yang signifikan hasil hasil ulangan akhir semester pada mata pelajaran IPA siswa kelas V di Gugus III Kecamatan Mendoyo atau dengan kata lain kemampuan siswa kelas V SD di Gugus III Kecamatan Mendoyo adalah setara.

Penentuan sampel dalam penelitian ini menggunakan teknik random sampling.Sugiyono (2015:120) menyatakan "random sampling adalah pengambilan anggota sampel dari populasi yang dilakukan secara acak tanpa memperhatikan strata yang ada dalam populasi itu. Sampel penelitian ini 
adalah 2 kelas yaitu kelas $\mathrm{V}$ yang diambil dari populasi, sekolah yang terpilih menjadi sampel penelitian yaitu SDN 8 Penyaringan dengan jumlah siswa 21 orang terpilih sebagai kelompok eksperimen dan SDN 1 Penyaringan dengan jumlah siswa 23 orang terpilih sebagai kelompok kontrol.

Instrumen pengumpulan data merupakan alat-alat yang digunakan untuk mengumpulkan data dalam penelitian.Instrumen pada penelitian ini dibuat dalam bentuk tes pilihan ganda (objektif).Tes pilihan ganda ini mengungkapkan tentang penguasaan siswa terhadap pelajaran IPA yang mereka peroleh di kelas.Melalui tes pilihan ganda dapat mengukur ranah kognitif dari yang sederhana sampai kompleks, dan penskoran dapat dilakukan secara objektif.Tes ini diberikan pada saat post-test. Untuk jawaban benar mendapatkan skor 1 (satu) dan jawaban salah mendapatkan skor 0 (nol).

Agar instrument ini memenuhi isyarat dengan baik instrumen penelitian tersebut terlebih dahulu dianalisis menggunakan uji validitas isi yang umum digunakan adalah teknik kecocokan para ahli (uji pakar).Uji validitas isi, reliabilitas, taraf kesukaran, dan daya beda.Tetapi sebelum melakukan uji coba instrumen terlebih dahulu melakukan uji validitas isi oleh kedua para pakar, setelah mendapatkan pertimbangan dari kedua pakar selanjutnya isntrumen tersebut di uji cobakan pada kelas VI yang telah mendapatkan materi, untuk mengetahui secara empirik istrumen itu layak untuk dipergunakan sebagai instrumen penelitian.

Setelah melakukan post-test, selanjutnya data tersebut dianalisis menggunakan statistik inferensial, analisis deskriptif digunakan untuk mengetahui tinggi rendahnya kualitas dari dua variabel Untuk menentukan tinggi rendahnya kualitas variabel-variabel tersebut, skor rata-rata (mean), modus, median, tiap-tiap variabel dikonversikan dengan menggunakan kriteria rata-rata ideal dan standar deviasi (SD). Sebelum melakukan uji hipotes terlebih dahulu melakukan uji normalitas dilakukan untuk menyajikan bahwa sampel benar-benar berasal dari populasi yang berdistribusi normal. Uji normalitas untuk skor penguasaan hasil belajar IPA siswa digunakan analisis Chi-Kuadrat. Kriteria pengujian, data berdistribusi normal jika $\chi^{2}$ hit $<\chi^{2}$, dengan taraf signifikasi 5\% dan derajat kebebasannya $\mathrm{dk}=$ (jumlah kelas parameter - 1) dan apabila $X_{\text {hitung }}^{2}>X_{\text {tabel }}^{2}$ maka data tidak berdistribusi normal.Uji homogenitas bertujuan untuk mengetahui bahwa kedua kelompok mempunyai varians yang sama. Kriteria pengujian, jika jika $F_{\text {hitung }}>F_{\text {tabel }}$ maka sampel tidak homogen dan jika $F_{\text {hitung }}<F_{\text {tabel }}$ maka sampel homogen.Pengujian dilakukan pada taraf signifikan $5 \%$ dengan derajat kebebasan untuk pembilang $n_{1}-1$ dan derajat kebebasan untuk penyebut $\mathrm{n}_{2}-1$.

Setelah data diketahui berdistribusi normal, selanjutnya dilakukan uji hipotesis dengan menggunkan uji-t, dalam penelitian ini rumus yang digunakan rumus polled varians yaitu sebagai berikut

$$
t=\frac{\bar{X}_{1}-\bar{X}_{2}}{\sqrt{\frac{\left(n_{1}-1\right) S_{1}^{2}+\left(n_{2}-1\right) S_{2}^{2}}{n_{1}+n_{2}-2}\left(\frac{1}{n_{1}}+\frac{1}{n_{2}}\right)}}
$$

(dalam Koyan, 2012:33)

Kriteria pengujian, jika $t_{\text {hitung }}>t_{\text {tabel }}$ maka $\mathrm{H}_{0}$ ditolak atau $\mathrm{H}_{1}$ diterima.Ini berarti terdapat perbedaan hasil belajar antara kelompok eksperimen dan kelompok kontrol. Tetapi jika $t_{\text {hitung }}>t_{\text {tabel }}$ maka $\mathrm{H}_{0}$ diterima atau $\mathrm{H}_{1}$ ditolak. Ini berarti tidak dapat perbedaan hasil belajar antara kelompok eksperimen dan kelompok kontrol.

\section{Hasil dan Pembahasan}

Data hasil belajar IPA pada kelompok eksperimen yang dibelajarkan dengan menggunakan model pembelajaran science environment technology society meenunjukkan bahwa skor tertinggi 24 dan skor terendah adalah 19. Hasil belajar siswa setelah melakukan post-test yaitu IPA kelompok eksperimen, yaitu mean $(M)=20.98$, median $(M d)=21.07$, modus $(M o)=21.10$, varians $\left(s^{2}\right)=5.59$ dan standar deviasi $(\mathrm{s})$ = 2.36. Mean (M), median (Md), modus (Mo) hasil belajar IPA siswa kelompok eksperimen selanjutnya disajikan ke dalam kurva polygon seperti pada gambar. Tujuan menyajikan data ini adalah untuk mendeskripsikan sebaran data hasil belajar IPA pada kelompok eksperimen. 


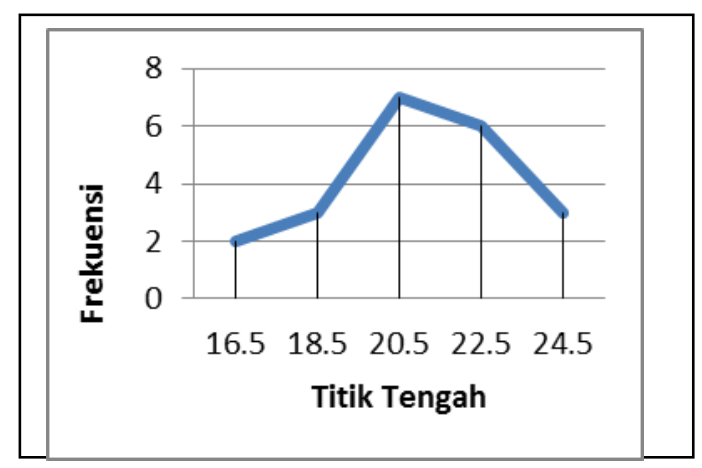

Gambar 1. Kurva Poligon Data Hasil Belajar IPA

Kelompok Eksperimen

Berdasarkan kurva polygon pada gambar 1, diketahui modus lebih besar dari median dan median lebih besar dari mean (Mo>Md>M), maka kurva juling negative.Hal ini berarti sebagian besar skor kelas eksperimen cenderung tinggi.

Data hasil belajar siswa kelompok kontrol yang dibelajarkan dengan menggunakan model pembelajaran konvensional menunjukan bahwa skor tertinggi adalah 18 dan skor terendah adalah 10 . Dari skor yang didapatkan nilai IPA kelompok kontrol, yaitu mean $(\mathrm{M})=14.67$, median $(\mathrm{Md})=14.62$, modus $(\mathrm{Mo})=14.50$, varians $\left(s^{2}\right)=3.81$ dan standar deviasi $(\mathrm{s})=1.95$. Mean $(\mathrm{M})$, median (Md), modus (Mo) hasil belajar IPA siswa kelompok kontrol selanjutnya disajikan ke dalam bentuk kurva polygon pada gambar 2 .

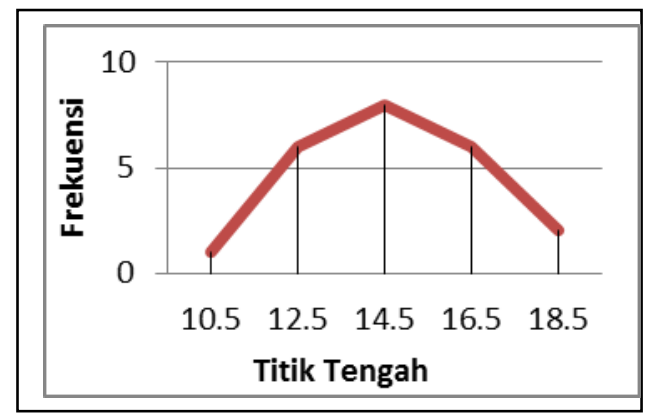

Gambar 2. Kurva Poligon Data Hasil Belajar IPA

Kelompok Kontrol

Berdasarkan kurva poligon pada gambar 2, dapat dilihat sebaran data kelompok siswa yang dibelajarkan menggunakan model pembelajaran konvensional menunjukkan mean lebih besar dari pada median dan modus( $\mathrm{M}>\mathrm{Md}>\mathrm{Mo}$ ), sehingga kurva yang terbentuk adalah kurva juling positif. Hal ini berarti sebagian besar skor cenderung rendah. Untuk mengetahui sebaran data hasil post test penguasaan kompetensi pengetahuan IPA kelompok eksperimen dan kelompok kontrol siswa berdistribusi normal atau tidak, maka data diuji menggunakan analisis Chi-Kuadrat $\left(\chi^{2}\right)$ pada taraf signifikasi $5 \%$ dan derajat kebebasan $\mathrm{dk}=\mathrm{k}$-parameter-1(dk= k-2-1).Sebelum melakukam uji hipotesis, terlebih dahulu melakukan uji normalitas dan homogenitas sebaran data.Berdasarkan hasil analisis data berdistribusi normal dan homogeny.Selanjutnya dilakukan uji hipotesis.Pengujian hipotesis $\mathrm{H}_{0}$ dan $\mathrm{H}_{1}$ dilakukan dengan menggunakan uji-t sampel independent (tidak berkorelasi). Karena $n_{1} \neq n_{2}$ dan hasil perhitungan varians menyatakan homogen, maka dalam pengujian digunakan rumus polled varians, dengan $\mathrm{db}=n_{1}+n_{2}-2$. Kriteria tolak $H_{0}$ jika $t_{h i t}>t_{t a b}$ dan terima $H_{0}$ jika $t_{h i t}<t_{t a b}$

Rangkuman hasil perhitungan uji-t antar kelompok eksperimen dan kontrol disajikan pada tabel 1. 
Tabel 1. Rangkuman Perhitungan Hasil Uji-t

\begin{tabular}{cccccccc} 
Data Hasil Belajar & Mean & Varians & $\mathrm{N}$ & $\mathrm{Db}$ & $\mathrm{t}_{\text {hitung }}$ & $\mathrm{t}_{\text {tabel }}$ & Kesimpulan \\
\hline $\begin{array}{c}\text { Kelompok } \\
\text { Eksperimen }\end{array}$ & 20.98 & 5.59 & 21 & 42 & 9,707 & 2,000 & $\begin{array}{c}\mathrm{t}_{\text {hitung }}>\mathrm{t}_{\text {tabel }} \mathrm{H}_{0} \\
\text { ditolak }\end{array}$ \\
Kelompok Kontrol & 14.67 & 3.81 & 23 & & & & \\
\hline
\end{tabular}

Berdasarkan tabel hasil perhitungan uji-t di atas diperoleh $\mathrm{t}_{\text {hitung }}$ sebesar, sedangkan $t_{\text {tab }}$ dengan $\mathrm{db}$ $=(21+23)-2=42$ dan taraf signifikansi $5 \%$ adalah 2,000. Karena $t_{\text {hitung }}>t_{\text {tabel }}(9,707>2.000)$ maka $\mathrm{H}_{0}$ ditolak dan $\mathrm{H}_{1}$ diterima. Hal ini berarti terdapat perbedaan hasil belajar IPA antara kelompok siswa yang dibelajarkan menggunakan model pembelajaran science environment technology society dan kelompok siswa yang dibelajarkan menggunakan model pembelajaran konvensional pada siswa kelas V SD di Gugus III Kecamatan Mendoyo Tahun Pelajaran 2017/2018.

Penelitian ini menemukan adanya perbedaan hasil antara pembelajaran dengan menggunakan model pembelajaran Science Environment Technology Society (SETS) dan pembelajaran konvensional.Hasil yang diperoleh saat menggunakan model pembelajaran Science Environment Technology Society (SETS) lebih tinggi dibandingkan ketika menggunakan model pembelajaran konvensional.Maka dapat disimpulkan bahwa pembelajaran dengan menggunakan model science environment technology society berpengaruh terhadap hasil belajar siswa.Penyebab diperolehnya perbedaan hasil belajar IPA dipengaruhi oleh beberapa faktor.

Faktor pertama, pada model pembelajaran Science Environment Technology Society (SETS) siswa diberikan kesempatan untuk mengenal, mengamati dan memahami secara langsung permasalahan di lingkungan yang berkaitan dengan materi yang akan dibahas, sehingga siswa dapat termotivasi atau terangsang untuk bisa ikut mengatasi permasalahan tersebut, pada model SETS hal itu disebut langkah invitasi. Pada langkah invitasi dapat mengembangkan dimensi kognitif siswa dalam ranah C1 (mengenal), dan C2 (memahami).Hal tersebut juga dipaparkan oleh Rini (2017) "pembelajaran melalui pengamatan langsung dapat menjadikan belajar lebih bermakna dan berfungsi untuk memperkuat pemahaman siswa terhadap permasalahan yang di dapat".

Faktor kedua pada model pembelajaran Science Environment Technology Society (SETS), setelah siswa mengenal, mengamati dan memahami permasalahan yang telah dibebankan langkah selanjutnya yaitu langkah eksplorasi.Pada langkah eksplorasi siswa berusaha sendiri menemukan informasi yang berkaitan dengan masalah yang dihadapinya melalui teknologi, interaksi dengan teman, maupun pada saat observasi langsung ke lingkungan selanjutnya informasi yang sudah terkumpul dirangkum untuk dicari solusinya.Menemukan informasi secara langsung membuat siswa tidak mudah lupa tentang materi yang telah diberikan dibandingkan dengan menghafal materi pembelajaran. Ekplorasi yang dilakukan oleh siswa tentunya membantu didalam mengembangkan dimensi dalam ranah kognitif C4 (menemukan), dan C2 (merangkum). Sejalan dengan temuan Setiawan (dalam Handayani, 2014) salah satu cara yang efektif dalam membelajarkan suatu pengetahuan kepada siswa adalah dengan melalui belajar di lingkungan.

Faktor ketiga, siswa yang telah mendapatkan informasi selanjutnya informasi tersebut dianalisis bersama kelompoknya dengan melakukan diskusi untuk memecahkan permasalahan yang sedang dihadapi, pada langkah pembelajaran Science Environment Technology Society (SETS) ini disebut langkah solusi.Melakukan diskusi antar siswa maupun kelompok bertujuan untuk bertukar pikiran, ide-ide maupun gagasan-gagasan baru, tidak hanya itu pada langkah solusi ini juga mengembangkan dimensi kognitif dalam ranah C4 (mengalisis) dan C2 (mendiskusikan). Sejalan dengan pendapat Fitriani dkk (2012) dengan diskusi dapat memunculkan ide pada setiap siswa sehingga nantinya kemampuan belajar siswa akan meningkat.

Faktor keempat, langkah terakhir model science environment technology society (SETS) yang juga dapat mempengaruhi nilai hasil belajar siswa yaitu langkah aplikasi, pada langkah ini siswa dapat mempresentasikan hasil diskusi di depan kelas agar kelompok lain juga dapat mengetahui solusi atau pemikiran baru yang telah didapatkan dari masing-masing kelompok dan nantinya siswa juga dihimbau agar mengaplikasikan solusi yang telah didapat di lingungan sekitar. Hal tersebut juga membantu siswa mengembangkan nilai sosial peduli dengan lingkungan dan dimensi ranah kognitif C3 (mengaplikasikan dan mengemukakan).Sejalan dengan pendapat Hasanah dan Mahdian (2013) "kegiatan presentasi akan membuat siswa menjadi lebih berani dalam mengutarakan pendapat dan siswa dapat mengetahui pemikiran-pemikiran baru yang didapat dari kelompok lain".Berbeda halnya dengan pembelajaran konvensional yang merupakan pembelajaran yang biasa dilakukan oleh guru. Dalam proses pembelajaran terlihat bahwa guru memberikan materi pelajaran melalui metode ceramah, latihan soal-soal kemudian 
pemberian tugas pada siswa. Dalam pembelajaran konvensioanal yang menjadi pusat pembelajaran adalah guru, sehingga pandangan siswa hanya tertuju pada guru. Kegiatan pembelajaran tidak diselingi dengan permainan, sehingga siswa terlihat bosan dalam menerima materi yang diajarkan, dan setiap materi yang diberikan oleh guru akan cepat dilupakan oleh siswa. Hal ini dapat menyebabkan rendahnya hasil belajar IPA siswa.

Penelitian yang sama telah dilakukan oleh Widiantini (2017) melakukan penelitian yang berjudul "Model Pembelajaran SETS (Science, Environment, Technology and Society) Berbantuan Virtual LAB Berperngaruh Terhadap Kompetensi Pengetahuan IPA Siswa Kelas IV SD Gugus Mayor Metra Denpasar Utara Tahun Ajaran 2016/2017" Hasil penelitian menunjukkan terdapat perbedaan yang signifikan kompetensi pengetahuan IPA antara kelompok yang dibelajarkan dengan model pembelajaran SETS berbantuan Virtual Laboratorydengan kelompok siswa yang dibelajarkan dengan menggunakan pembelajaran konvensional pada siswa kelas IV SD Gugus Mayor Metra.

\section{Simpulan dan Saran}

Berdasarkan permasalahan yang dihadapi dan pembahasan yang telah diuraikan maka dapat disimpulkan bahwa terdapat perbedaan hasil belajar IPA antara kelompok siswa yang dibelajarkan menggunakan model science environment technology society (SETS) dengan kelompok siswa yang dibelajarkan menggunakan model pembelajaran konvensional pada siswa kelas V SD di Gugus III Kecamatan Mendoyo Kabupaten Jembrana tahun pelajaran 2017/2018. Perbedaannya dapat dilihat berdasarkan nilai hasil pengujian hipotesis dengan menggunakan uji-t diperoleh $t_{\text {hitung }}$ 9,707 dan $t_{\text {tabel }}$ dengan taraf signifikansi $5 \%$ dan $\mathrm{db}=42$ adalah 2,000. Ini berarti $\mathrm{t}_{\text {hitung }}>\mathrm{t}_{\text {tabel, }}$, sehingga $\mathrm{H}_{0}$ ditolak dan $\mathrm{H}_{1}$ diterima.Berarti model pembelajaran science environment technology society (SETS) memiliki pengaruh terhadap hasil belajar IPA siswa kelas V SD di Gugus III Kecamatan Mendoyo Kabupaten Jembrana tahun pelajaran 2017/2018.

Saran yang diajukan berdasarkan hasil penelitian dan pembahasan adalah sebagai berikut, (1) kepada siswa di sekolah dasar agar lebih aktif dalam mengikuti proses pembelajaran dan terus mengembangkan pemahamannya dengan membangun pengetahuan sendiri melalui pengalaman sehingga dapat meningkatkan hasil belajar; (2) kepada guru agar lebih kreatif dan berinovasi dalam memilih model pembelajaran untuk meningkatkan minat belajar siswa, demi meningkatkan hasil belajar siswa; (3) kepada kepala sekolah agar selalu berusaha memfasilitasi rekan-rekan guru lainnya agar mampu menggunakan berbagai macam model atau metode pembelajaran yang lebih bervariasi di dalam proses pembelajaran sehingga hasil belajar siswa meningkat; (4) kepada peneliti lain agar memperhatikan kendala yang dialami dalam pelaksanaan model pembelajaran science environment technology society khususnya dalam mata pelajaran IPA agar penelitian yang akan dilaksanakan lebih sempurna.

\section{Daftar Rujukan}

Fatchan, Ahmad. 2014. Pengaruh Model Pembelajaran Science, Evironment, Technology And Society (SETS) Terhadap Kemampuan Berkomunikasi Secara Tertulis Berupa Penulisan Karya Ilmiah Bidang Geografi Siswa SMA. e-jurnal pendidikan dan pembelajaran volume 21 nomer 1 tahun 2014.

Handayani, Ni L Pt Andry, dkk. 2014. Pengaruh PendekatanScience,Environment,Technology And Society(Sets)MelaluiKerjaKelompokBerbasis Lingkungan TerhadapHasil Belajar IPASiswaKelasVSDN 9Sesetan,Denpasar. Jurnal Volume 2 Nomer 1.Singaraja. Undiksha Singaraja.

Hasanah, Aan dan Mahdian.2013. Penerapan Pendekatan SETS (Science Environment Technology Society) Pada Pembelajaran Reaksi Reduksi Oksidasi.Jurnal Inovasi Pendidikan Sains. Banjarmasin. Universitas Lambung Mangkurat.

Rasana, I Dewa Putu Raka.2009. Laporan SabbaticalLeave Model-Model Pembelajaran. Singaraja: Universitas Pendidikan Ganesha.

Riastini, Putu Nanci., dkk. 2016. Pembelajaran IPA SD. Singaraja. Undiksha Singaraja.

Rusman. 2015. Pembelajaran Tematik Terpadu Teori, Praktik Dan Penilaian. Jakarta: PT RajaGrafindo Persada.

Samatowa, Usman. 2010. Pembelajaran IPA di Sekolah Dasar. Jakarta Barat.Permata Kuri Media. 
Sutarno, Nono. 2009. Materi dan Pembelajaran IPASD. Jakarta: Universitas Terbuka.

Widiantini, dkk. 2017. Model Pembelajaran SETS (Science, Evironment, Technology And Society) Berbantuan Virtual Lab Berpengaruh Terhadap Hasil belajar IPA. Jurnal volume 1 Nomer 2.Singaraja. Undiksha Singaraja

Koyan, I Wayan.2012. Teknik Analisis Data Kuantitatif.Singaraja: Universitas Pendidikan Ganesha Press.

Suastra, I Wayan. 2009. Pembelajaran Sains Terkini: Mendekatkan Siswa dengan Lingkungan Alamiah dan Sosial Budayanya. Cetakan Ke-1. Singaraja: Undiksha

Trianto. 2010. Model Pembelajaran Terpadu: Konsep, Strategi, dan Implementasinya dalam Kurikulum Tingkat Satuan Pendidikan (KTSP).Cetakan Ke-2. Jakarta: PT Bumi Aksara.

Jihad, Asep dan Abdul Haris. 2013. Evaluasi Pembelajaran. Yogyakarta: Multi Pressindo. 